\title{
Review
}

\section{5-Phenyl-2-furaldehyde: Synthesis, Reactions and Biological Activities}

\author{
A.S. Hassan*, Souad A. Osman and Taghrid S. Hafez \\ Department of Organometallic and Organometalloid \\ Chemistry, National Research Centre, El-Buhoth St., Dokki, \\ Giza, Egypt.
}

\begin{abstract}
5 -PHENYL-2-furaldehyde is a good starting material for designing of polyfunctionalized heterocyclic compounds with pharmacological interest such as antimicrobial and antitumor activities. This review article focused on some synthetic methods, reactions and biological activities of 5-phenyl-2-furaldehyde.
\end{abstract}

Keywords: 5-Phenyl-2-furaldehyde, Synthesis, Palladium-catalyzed, Chemical reactions and Biological activities.

Compounds bearing oxygen heterocycles are well known to be biologically important ${ }^{(1)}$. On the other side, compounds containing furan moiety show a diverse array of favorable pharmacological properties and have consequently been used as medicines in a variety of different diseases areas ${ }^{(2)}$. Furan derivatives obtained from natural and synthetic sources have been a subject of considerable interest for their wide range of pharmaceutical applications ${ }^{(3-6)}$. A large number of naturally occurring compounds bearing furan have shown interesting biological activities such as antimicrobial ${ }^{(7,8)}$, cytotoxic and antitumor properties $^{(9)}$, as well as of other potentially useful activities ${ }^{(10,11)}$.

Literature survey, as far as we are aware, revealed that some drugs bearing furan moiety are considered as the most active in manufactured drugs such as Dantrolene (Muscle relaxant), Furosemide (Antihypertensive), Nifurtimox (Antiprotozoal), Nifuroxazide (antibiotic), Nifurprazine (Antibacterial), Furfenorex (Anorexic), Dormovit (Sedative, hypnotic) and Methafurylene (Antihistaminic). The structures of these drugs are shown in Fig. 1.

5-Phenyl-2-furaldehyde (Fig. 2) and its derivatives have been reported for their interesting pharmacological activities e.g. antibacterial ${ }^{(12)}$, antitumor ${ }^{(13)}$, inhibitors of phosphoinositide 3-Kinase $\gamma^{(14)}$, HCV NS5B polymerase ${ }^{(15)}$ and non-thiol farnesyltransferase ${ }^{(16)}$.

\footnotetext{
*E-mail: Ashraf_salmoon@yahoo.com (A. S. Hassan)
} 

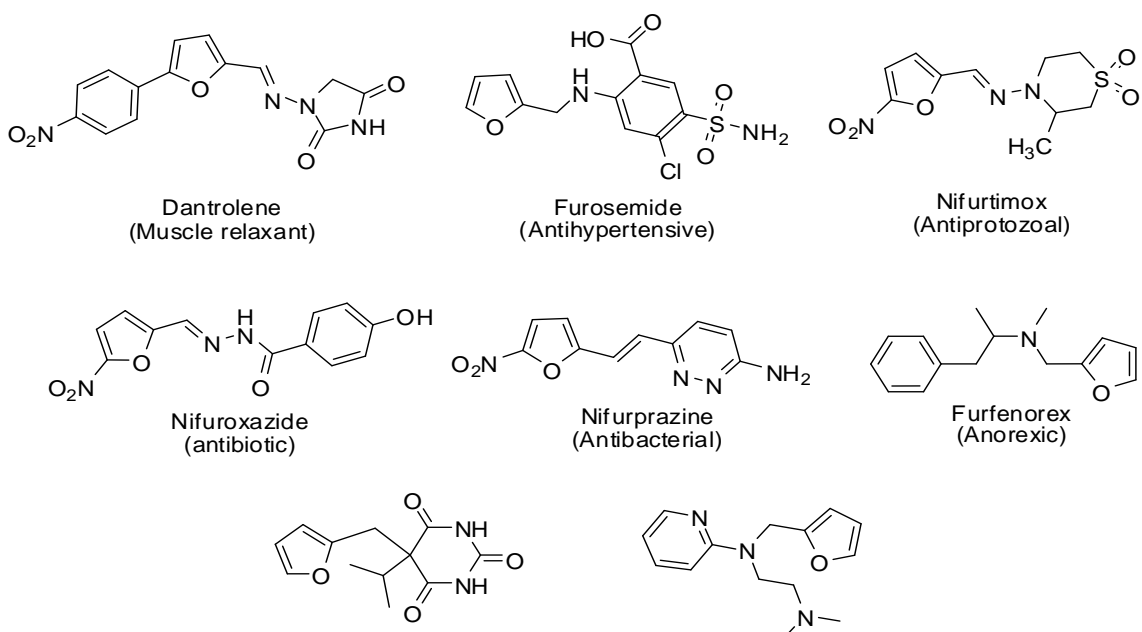

Dormovit
(Sedative, hypnotic)

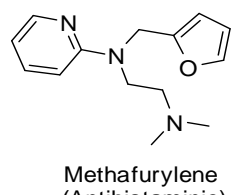

(Antihistaminic)

Fig. 1. The structures of some drugs bearing furan moiety.

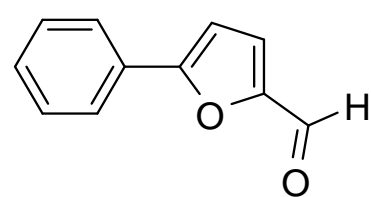

3

Fig. 2. The structure of 5-phenyl-2-furaldehyde 3.

Therefore, the objective of the present work is to shed more light on the synthesis, reactions and biological activities of 5-phenyl-2-furaldehyde.

\section{Synthetic Methods}

5-Phenyl-2-furaldehyde can be synthesized via the following reactions:

The coupling reaction with copper(II)-catalyzed (Meerwein arylation)

5-Phenyl-2-furaldehyde 3 was prepared by coupling benzene diazonium chloride 1 with 2-furaldehyde 2 in the presence of cupric chloride (Scheme 1) ${ }^{(17-18)}$.

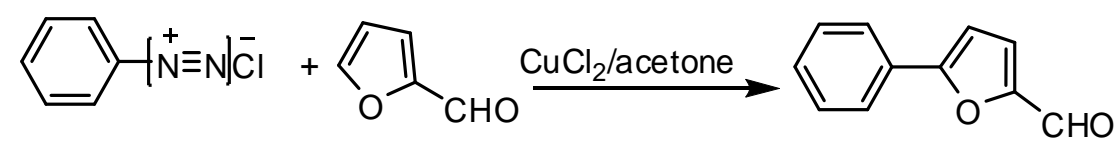

1

2

Scheme 1.

Egypt. J. Chem. 58, No. 2 (2015) 
Vilsmeier-Haack reaction

5-Phenyl-2-furaldehyde (3) (yield: 60\%) was synthesized from 2-phenylfuran (4) via a Vilsmeier-Haack reaction (Scheme 2$)^{(19)}$.

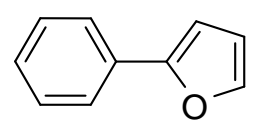

4

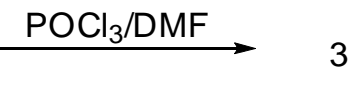

Scheme 2

Photochemical reaction

Irradiation of 5-bromofuran-2-carbaldehyde (5) in benzene solution furnished 3 in yield $64 \%,{ }^{(20)}$ but using 5-iodofuran-2-carbaldehyde (6) gave yield 91\% (Scheme 3) $^{(21)}$.

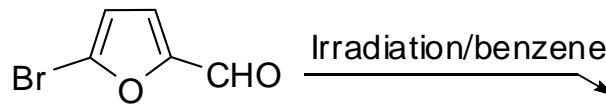

5

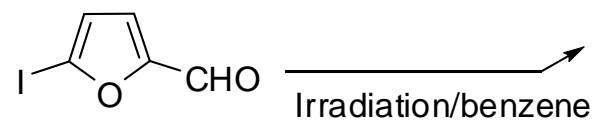

6

Scheme 3

Palladium(II) acetate catalyzed reaction

Oxidation of 2-furaldehyde (2) by palladium(II) acetate in acetic acid containing benzene at reflux temperature gave 3 (Scheme 4) ${ }^{(22)}$.

$$
\begin{gathered}
\stackrel{[\mathrm{O}] / \mathrm{Pd}(\mathrm{OAc})_{2} / \mathrm{AcOH}}{\text { benzene }} \\
\text { Scheme } 4
\end{gathered}
$$

Moreover, the coupling of phenyl boronic acid with 5 in water, in the presence of tetrabutylammonium bromide and palladium(II) acetate at room temperature (RT) yielded 5-phenyl-2-furaldehyde 3 (yield: 74\%) (Scheme 5) ${ }^{(23)}$.

5

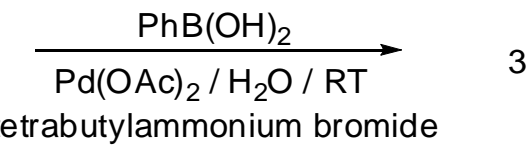

Scheme 5

Egypt. J. Chem. 58, No. 2 (2015) 
$5 \% \mathrm{Pd}\left(\mathrm{PPh}_{3}\right)_{2} \mathrm{Cl}_{2}$ catalyzed

5-Phenyl-2-furaldehyde (3) was prepared from 5 and phenyl tributyl tin (7) in the presence of $5 \% \mathrm{Pd}\left(\mathrm{PPh}_{3}\right)_{2} \mathrm{Cl}_{2}$ in refluxing dichloroethane (yield: 61\%) (Scheme 6) ${ }^{(24)}$.

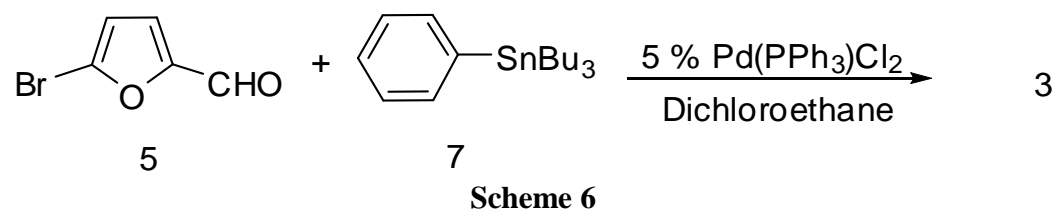

$\operatorname{Pd}($ dppf)Cl 2 : [1,1'-Bis(diphenylphosphino) ferrocene] dichloropalladium catalyzed

5-Phenyl-2-furaldehyde 3 was prepared from bromobenzene (8) and organozinc reagents (9a-c) in the presence of $\mathrm{Pd}(\mathrm{dppf}) \mathrm{Cl}_{2}$ as a catalyst (yields 9a: 77\%, 9b: 76\%, 9c: 71\%) (Scheme 7) ${ }^{(25)}$.

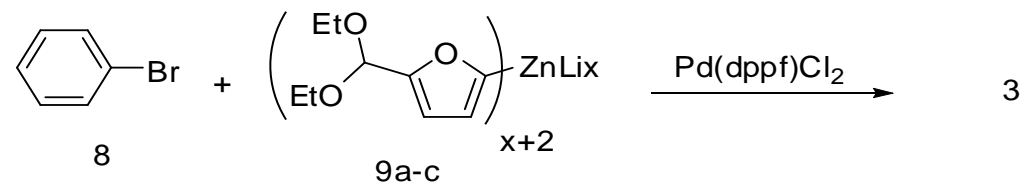

$9 a: x=0 ; 9 b: x=1 ; 9 c: x=2$

\section{Scheme 7}

\section{Palladium catalyst}

The cis,cis,cis-1,2,3,4-tetrakis (diphenylphosphinomethyl) cyclopentane/ $\left[\operatorname{PdCl}\left(\mathrm{C}_{3} \mathrm{H}_{5}\right)\right]_{2}$ complex catalyzed the Suzuki cross-coupling of 5 with phenyl boronic acid in dry xylene under argon to afford 3 (Scheme 8$)^{(26,27)}$.

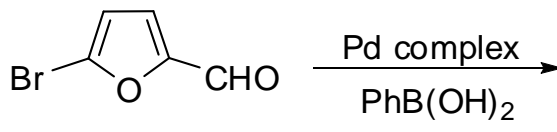

Scheme 8

Also, the Suzuki coupling of 5 with phenylboronic acid was catalyzed by trans- $\left(\mathrm{Cy}_{2} \mathrm{NH}\right)_{2} \mathrm{Pd}(\mathrm{OAc})_{2}$ (DAPCy) in EtOH under aerobic conditions to afford the coupled product 3 in yield $91 \%$ (Scheme 9$)^{(28)}$.

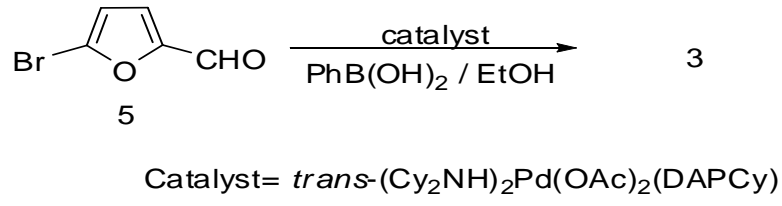

Scheme 9

Egypt. J. Chem. 58, No. 2 (2015) 


\section{Palladium-catalyzed Hiyama cross-coupling}

5-Chlorofuran-2-carbaldehyde (10) was coupled with phenyltrifluorosilane (11) in the presence of $\mathrm{Pd}(\mathrm{OAc})_{2}$ as a catalyst to afford the coupled product, 5phenyl-2-furaldehyde (3) (yield: 74\%) (Scheme 10) ${ }^{(29)}$.

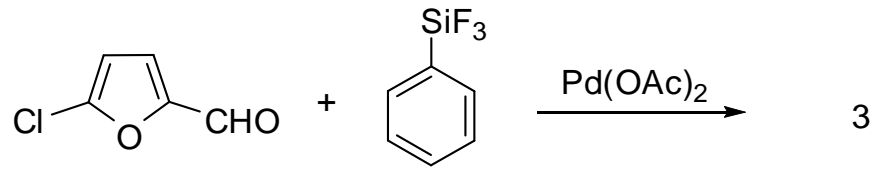

10

11

Scheme 10

Suzuki coupling reaction

5-Chlorofuran-2-carbaldehyde (10) can be arylated with phenylboronic acid in the presence of the PAP ligand [2-(di-tert-butylphosphino)-1-phenyl-1Hpyrrole] as a catalyc to form 3 (yield $>99 \%$ ) $(\text { Scheme } 11)^{(30)}$.

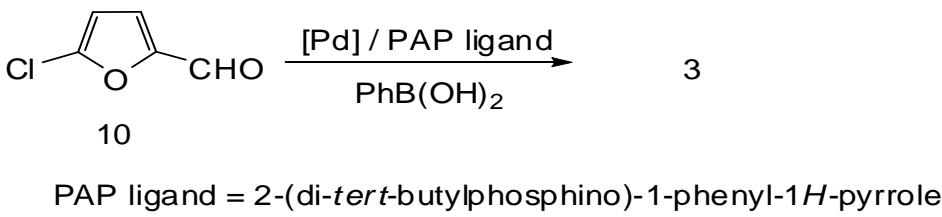

\section{Scheme 11}

\section{Suzuki-Miyaura reaction}

5-Phenyl-2-furaldehyde (3) can be prepared by reacting 5-bromo-2furaldehyde (5) with phenylboronic acid in the presence of $\mathrm{Pd}(\mathrm{OAc})_{2}$ and ligand 1 [glyoxal bis( $N$-methyl- $N$-phenyl-hydrazone)] as a catalyst under aerobic conditions (yield: $83 \%$ ) (Scheme 12) ${ }^{(31)}$.

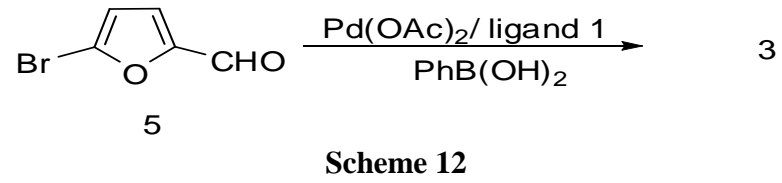

Also, 5-phenyl-2-furaldehyde 3 can be prepared by reacting 5 with phenylboronic acid via Suzuki-Miyaura reaction in the continuous flow reactor with using the palladium resin catalyst, $N, N$-diisopropyl ethyl amine in DMF/water at $100{ }^{\circ} \mathrm{C}$, (yield: $91 \%$ ) (Scheme 13$)^{(32)}$.

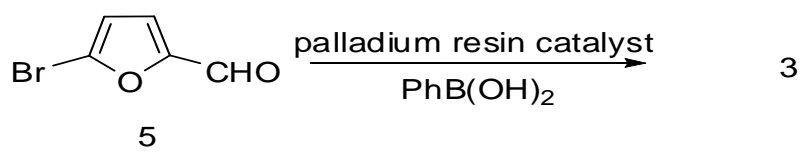

Scheme 13

Egypt. J. Chem. 58, No. 2 (2015) 
Moreover, the Suzuki-Miyaura reaction of 6 and phenylboronic acid catalyzed with using the membrane-installed microchannel device furnished 3 in high yield (99\%) (Scheme 14) ${ }^{(33)}$.

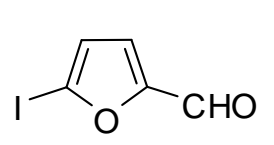

6

$$
\begin{aligned}
& \text { membrane-installed } \\
& \text { microchannel device }
\end{aligned}
$$$$
\mathrm{PhB}(\mathrm{OH})_{2}
$$

\section{Scheme 14}

The coupling reaction of $\mathrm{Ph}_{3} \mathrm{Bi}$ with 5-bromo-2-furaldehyde

The coupling reaction of 5 with $\mathrm{Ph}_{3} \mathrm{Bi}$ furnished 5-phenyl-2-furaldehyde (3) in high yield (89\%) with using $\mathrm{Pd}(\mathrm{OAc})_{2}$ as a catalyst and $\mathrm{Cs}_{2} \mathrm{CO}_{3}$ base in $\mathrm{N}$ methylpyrrolidone (NMP) solvent (Scheme 15) ${ }^{(34)}$.

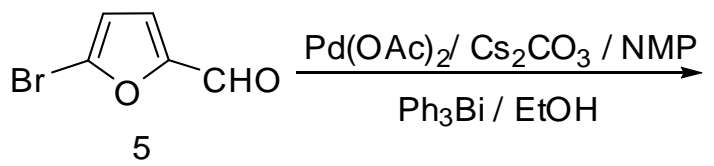

\section{Scheme 15}

\section{Chemical Reactions}

Formation of furfurylidene derivatives

The condensation of 3 and pentan-2,4-dion (12) in THF in the presence of $\mathrm{Cu}(\mathrm{II}) \mathrm{Cl}_{2}$ as a catalyst formed 3-[(5-phenylfuran-2-yl)methylene]pentane-2,4dione 13 in moderate yield (Scheme 16) ${ }^{(35)}$.

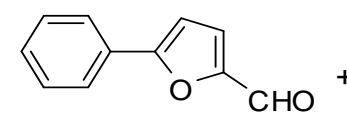

3<smiles>CC(=O)CC(C)=O</smiles>

12

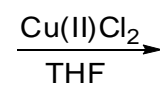

(1)

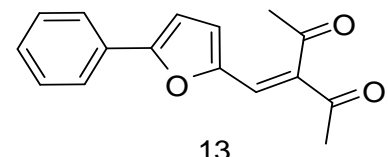

Scheme 16

6-(5-Phenyl-2-furfurylidene)-dibenzo[a,c]cyclohepten-5,7-dione (15) was prepared by the reaction of 6,6-dihydro-dibenzo[a,c]cyclohepten-5,7-dione (14) with 3 in benzene and 96\% ethanol (yield 70\%) (Scheme 17) ${ }^{(36)}$.

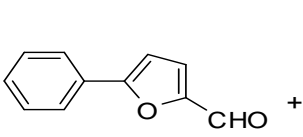

3

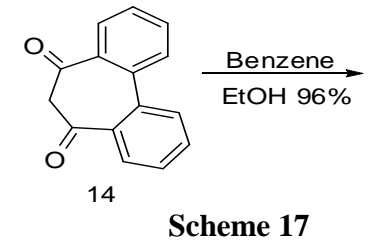

Scheme 17<smiles>O=C1C(=Cc2ccc(-c3ccccc3)o2)C(=O)c2ccccc2-c2ccccc21</smiles>

15

Egypt. J. Chem. 58, No. 2 (2015) 
Methyl-2-cyano-3-(5-phenyl-2-furyl)acrylate (16a) $(92 \%)^{(37)}$ or ethyl 2cyano-3-(5-phenyl-2-furyl)acrylate $16 \mathrm{~b}(72 \%)^{38}$ were prepared by the reaction of 3 with methyl cyanoacetate or ethyl cyanoacetate, respectively, via using the Knoevenagel reaction conditions, in dry ethanol with adding sodium ethoxide as a catalytic (Scheme 18).

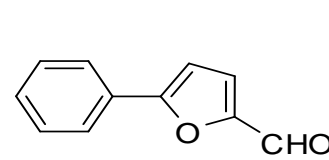

3

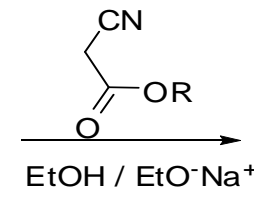

Scheme 18

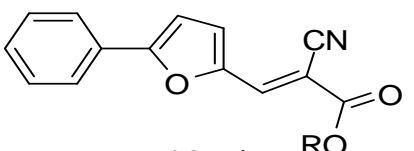

$16 \mathrm{a}, \mathrm{b}$

b; $\mathrm{R}=\mathrm{C}_{2} \mathrm{H}_{5}$

Reaction of 5-phenyl-2-furaldehyde 3 with cyanoselenoacetamide gave 2cyano-3-(5-phenyl-2-furyl)prop-2-eneselenoamide (17) (yield: 83\%) (Scheme 19) ${ }^{(39,40)}$.

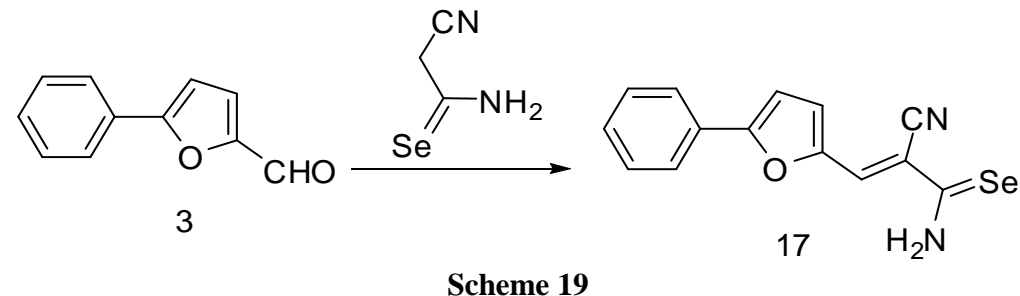

3-Amino-2-butanenitrile was first hydrolyzed by dilute $\mathrm{HCl}$ in ethanol to yield cyanoacetone, which, upon Knoevenagel condensation with 3 and then neutralization afforded 3-oxo-2-[(5-phenylfuran-2-yl)methylene]butanenitrile (18) in yield $91 \%$ (Scheme 20$)^{(41)}$.

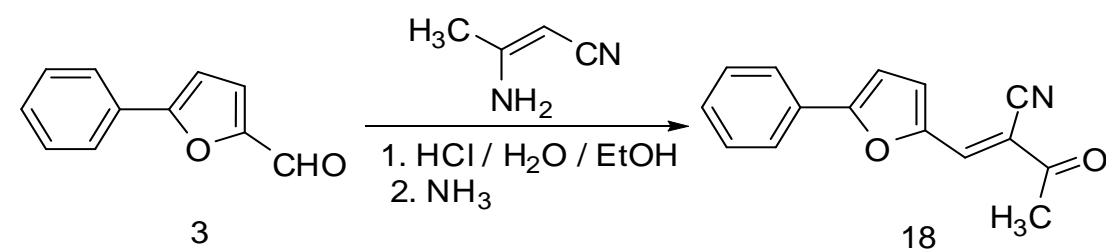

Scheme 20

Condensation of 5-phenyl-2-furaldehyde (3) with 5-nitrofurfuryl phenyl sulfone or 5-nitrofurfuryl trichloromethyl sulfone afforded 1-(5-nitro-2-furyl)-1-phenyl sulfonyl-2-(5-phenyl-2-furyl) ethylene (19a) ${ }^{(42)}$ r 1-(5-nitro-2-furyl)-1-trichloromethyl sulfonyl-2-(5-phenyl-2-furyl) ethylene (19b) ${ }^{(43)}$, respectively (Scheme 21). 


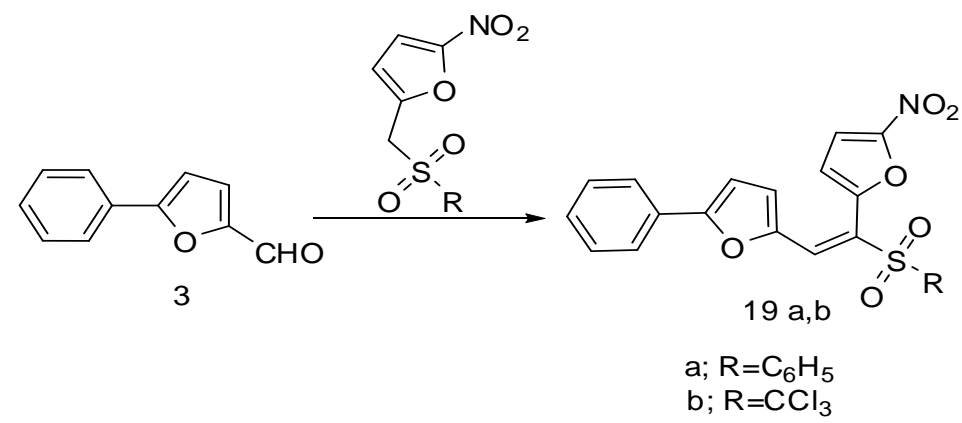

Scheme 21

1-Phenyl sulfonyl-1-cyano-2-(5-phenyl-2-furyl) ethylene (20) (yield: 68\%) was prepared by the condensation of 3 with phenyl sulfonyl acetonitrile (Scheme 22) ${ }^{(44)}$.

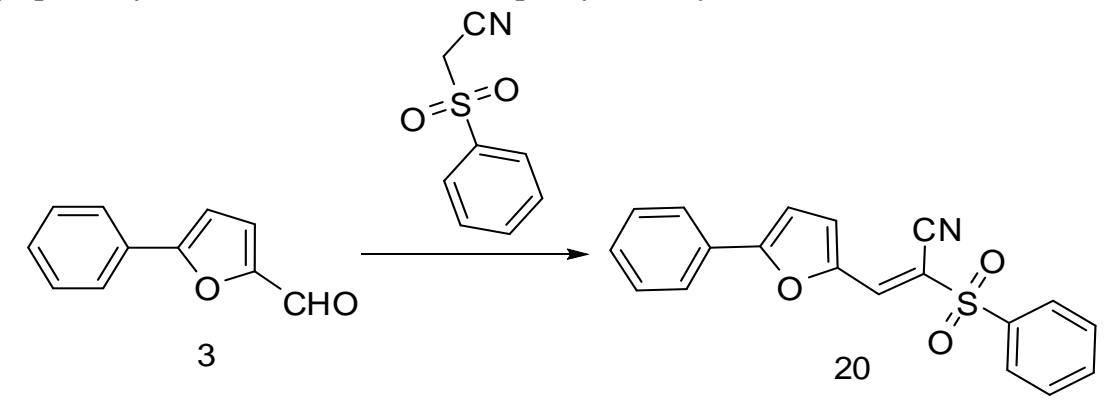

Scheme 22

3,4-Dichlorophenylacetonitrile treated with 5-phenyl-2-furaldehyde (3) in water with adding $40 \% \mathrm{PhCH}_{2} \mathrm{NMe}_{3}(\mathrm{OH})$ as a catalyst at $50{ }^{\circ} \mathrm{C}$ for $5 \mathrm{hr}$ gave $(\mathrm{Z})$ 2-(3,4-dichlorophenyl)-3- (5-phenyl-2-furyl) acrylonitrile (21) in yield 94\% (Scheme 23) $^{(13)}$.

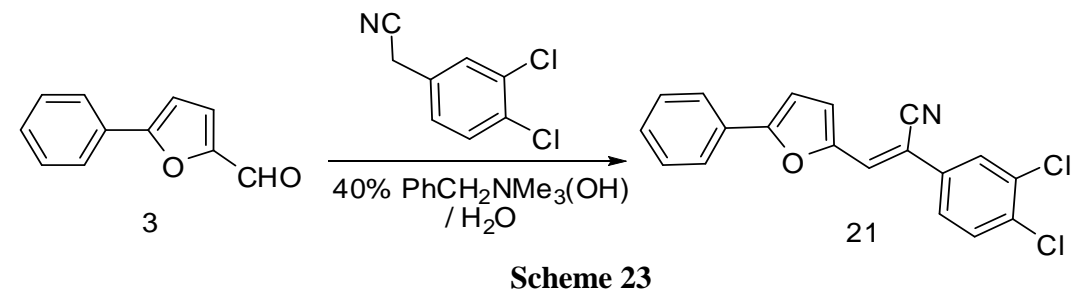

2-Cyanomethylbenzimidazole reacted with 5-phenyl-2-furaldehyde (3) to afford a condensation product, 3-(5-phenyl-2-furyl)-2-(2- enzimidazolyl) crylonitrile 22 in a high yield. The carboxylic acid chloride (23) was prepared from ethyl 2-cyano-3-(5-phenyl-2-furyl)acrylate (16b) which was in turn synthesized by condensation of 5-phenyl-2-furaldehyde (3) with ethyl cyanoacetate. Compound 23 and o-phenylenediamine when heated in DMF formed 22 (Scheme 24) ${ }^{(45)}$.

Egypt. J. Chem. 58, No. 2 (2015) 


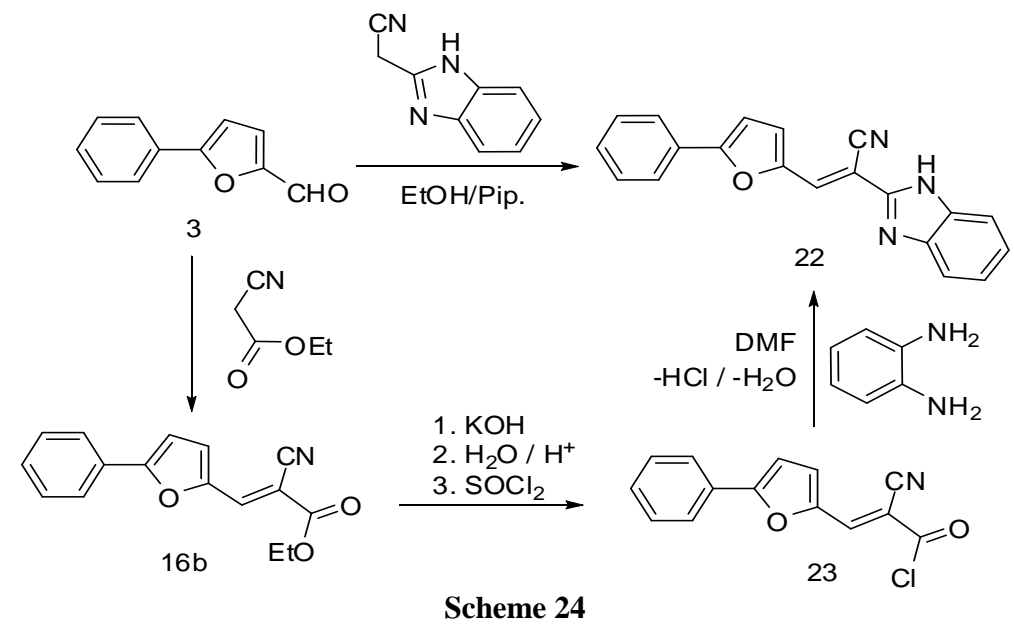

5-[(5-Phenyl-2-furyl)methylene]thiazolidine-2,4-dione (24) was prepared by the condensation of 5-phenyl-2-furaldehyde (3) with thiazolidine-2,4-dione in the presence of $\beta$-alanine in acetic acid (Scheme 25) ${ }^{(14)}$.

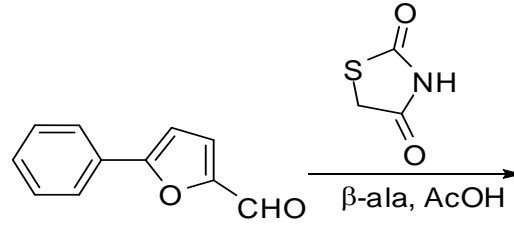

3

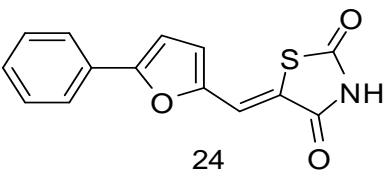

Scheme 25

Rhodanine was condensed with 5-phenyl-2-furaldehyde (3) in the presence of piperidine in ethanol to afford (Z)-5-((5-phenylfuran-2-yl) methylene)-2thioxothiazolidin-4-one (25), which then reacted with $\mathrm{CH}_{3} \mathrm{I}$ to form the methyl thio-derivative (26) (Scheme 26) ${ }^{(46)}$.

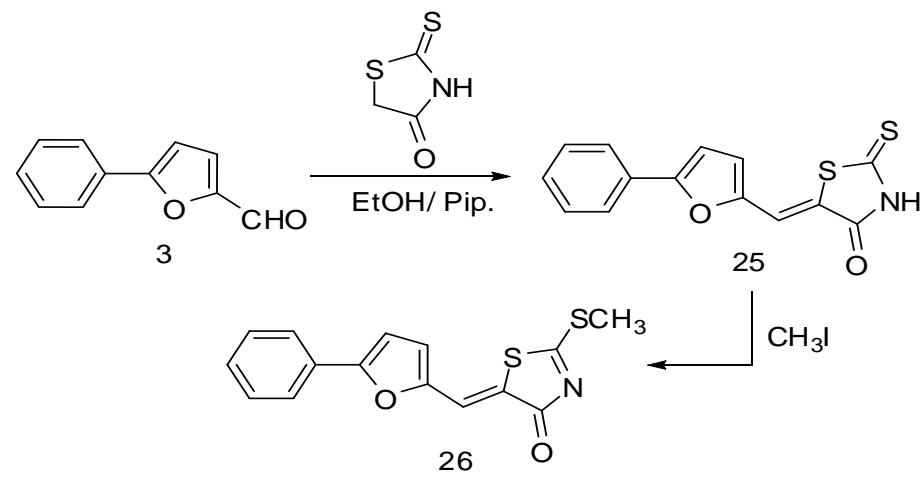

Scheme 26

Egypt. J. Chem. 58, No. 2 (2015) 
(Z)-3-Methyl-2-(4-oxo-5- ((5-phenylfuran-2-yl) methylene)-2-thioxothiazolidin3-yl) pentanoic acid (27a) ${ }^{(47)}$, (Z)-2-(4-oxo-5- ((5-phenylfuran-2-yl) methylene)-2thioxothiazolidin-3-yl) -3-phenyl propanoic acid (27b) ${ }^{(47)}$ and (Z)-2-(4-oxo-5- ((5phenylfuran-2-yl)methylene)-2 -thioxothiazolidin-3-yl) acetic acids (27c) ${ }^{(48)}$ were obtained via the Knoevenagel condensation reaction of the 5-phenyl-2- furaldehyde (3) with the $N$-substituted rhodanine, e.g. (2S)-3-methyl-2- (4-oxo-2thioxothiazolidin-3-yl) pentanoic acid, (S)-2-(4-oxo-2-thioxo-thiazolidin-3-yl)-3phenylpropanoic acid and rhodanine-3-acetic acid, respectively (Scheme 27).

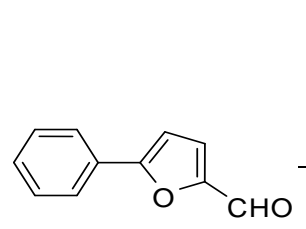

3<smiles>[R]C(C(=O)O)N1C(=O)CSC1=S</smiles>

$\mathrm{EtOH} / \mathrm{AcOH}$<smiles>[R]C(C(=O)O)N1C(=O)/C(=C/c2ccc(-c3ccccc3)o2)SC1=S</smiles>
$27 a-c$

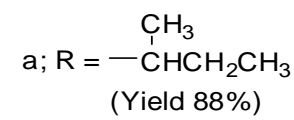<smiles>[R]#CCc1ccccc1</smiles>
$\mathrm{c} ; \mathrm{R}=-\mathrm{H}$ (Yield 88\%)

(Yield 78\%)

Scheme 27

5-Phenyl-2-furaldehyde (3) condensed with 4-methyl - $N$-(2-oxo-2,5dihydrothiazol-4-yl) benzenesulfonamide in $n$ - BuOH to form (Z)-4- methyl- $N$ \{2-oxo-5- [(5-phenylfuran-2-yl) methylene ] -2,5-dihydrothiazol-4-yl\} benzenesulfonamide (28) in yield 75\% (Scheme 28$)^{(15)}$.

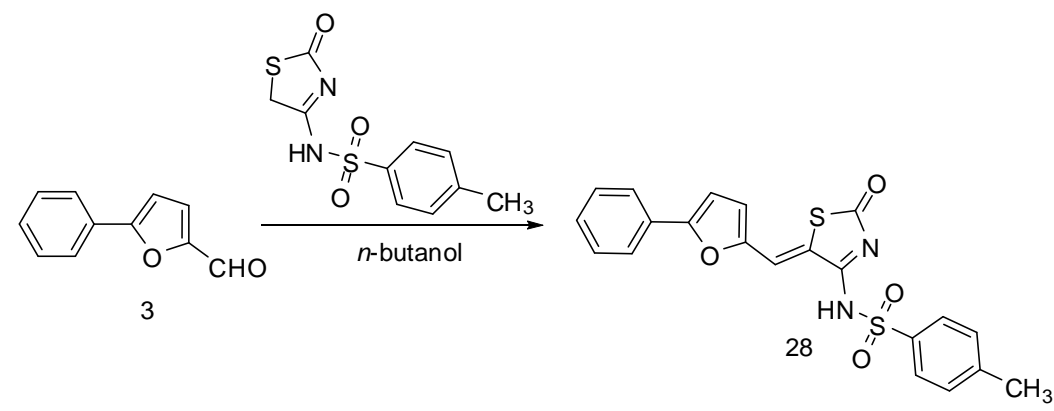

Scheme 28

3-(4-Methoxybenzyl)-2- (4-methoxybenzylimino)-5- [(5-phenylfuran-2yl)methylene] thiazolidin-4-one (29) (yield: 51\%) was synthesized by one-pot reaction of 4-methoxybenzylamine, 4-methoxybenzylisothiocyanate with chloroacetyl chloride and 5-phenylfuran-2-carbaldehyde (3) (Scheme 29) ${ }^{(49)}$. 


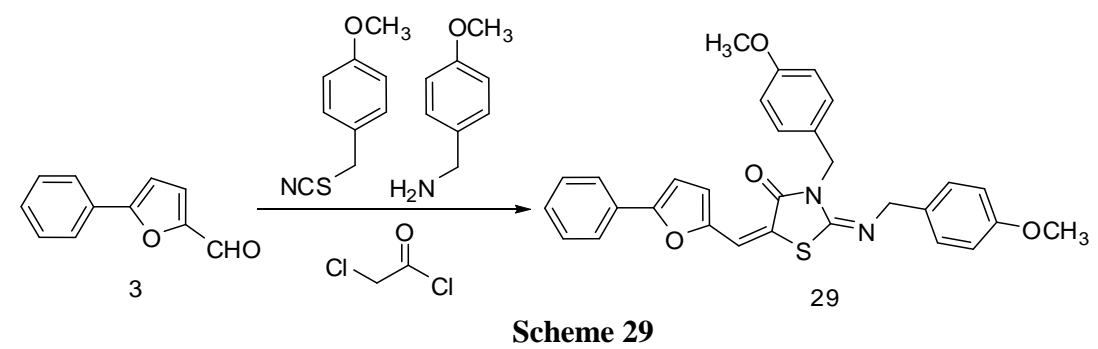

Chalcone derivatives

1-(2-Furoyl)-2-(5-phenylfuran-2-yl)ethylene $\quad(30 a)^{(50)}$, 1-benzoyl-2-(5phenylfuran-2-yl)ethylene (30b) ${ }^{(50)}$ and 1-(5-nitro-2-furoyl)-2-(5-phenylfuran-2yl)ethylene (30c) ${ }^{(51)}$ have been synthesized by the condensation of 5-phenyl-2furaldehyde (3) with 2-acetylfuran, acetophenone and 5-nitro-2-acetylfuran, respectively (Scheme 30 ).<smiles>O=Cc1ccc(-c2ccccc2)o1</smiles>

3<smiles>[R]C(=O)/C=C/c1ccc(-c2ccc(CC(C)=O)cc2)o1</smiles>

30a-c<smiles>[R]c1ccco1</smiles>

$\mathrm{b} ; \mathrm{R}$<smiles>[R]c1ccccc1</smiles><smiles>[R]c1ccc([N+](=O)[O-])o1</smiles>

Scheme 30

Methyl 3-(5-phenylfuran-2-yl)acrylate 31 (yield: 80\%) was prepared from 5phenyl-2-furaldehyde (3) by Reformatsky reaction (Scheme 31$)^{(52)}$.

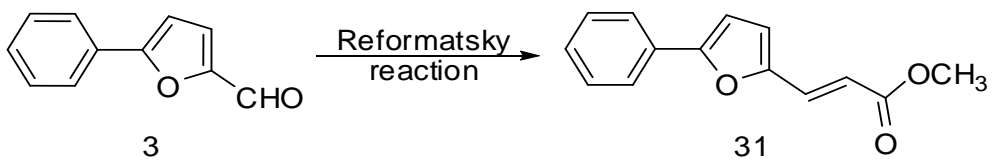

\section{Scheme 31}

5-Phenyl-2-furaldehyde (3) was coupled with isoprene to form 2,3-dimethyl1-(5-phenylfuran-2-yl)but-3-en-1-one (32) in good yield (90\%). This coupling reaction was accamplished using ruthenium dihydride complex $\mathrm{RuH}_{2}(\mathrm{CO})\left(\mathrm{PPh}_{3}\right)_{3}$ catalyst activated by trifluoroacetic acid (Scheme 32) ${ }^{(53)}$.<smiles>O=Cc1ccc(-c2ccccc2)o1</smiles>

3

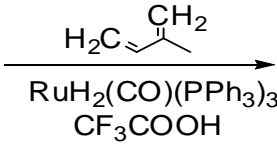

Scheme 32

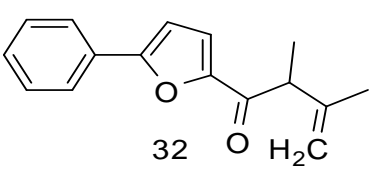

Egypt. J. Chem. 58, No. 2 (2015) 
Hydrazide and hydrazone derivatives

5-Phenyl-2-furaldehyde (3) reacted with hydroxylamine hydrochloride in the presence of sodium acetate in ethanol to yield $(E)$-5-phenylfuran-2-carbaldehyde oxime (33) (Scheme 33) ${ }^{(54)}$.

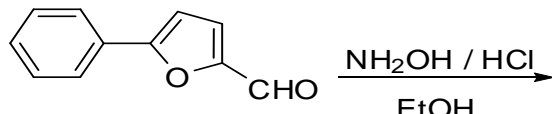

$\mathrm{EtOH}$

Scheme 33<smiles>O/N=C/c1ccc(-c2ccccc2)o1</smiles>

33

A series of 5-phenyl-2-furancarbaldehyde 2,6-dialkylphenylhydrazone (34ac) was prepared in excellent yield by the reaction of 5-phenyl-2-furaldehyde (3) with 2,6-dialkylphenylhydrazine. On the other hand, 5-phenyl-2furancarbaldehyde dimethylhydrazone (35) was prepared by the reaction of 3 with $\mathrm{N}, \mathrm{N}$-dimethylhydrazine in refluxing toluene in the presence of catalytic amount of 4-methylbenzenesulfonic acid (Scheme 34) ${ }^{(55)}$.

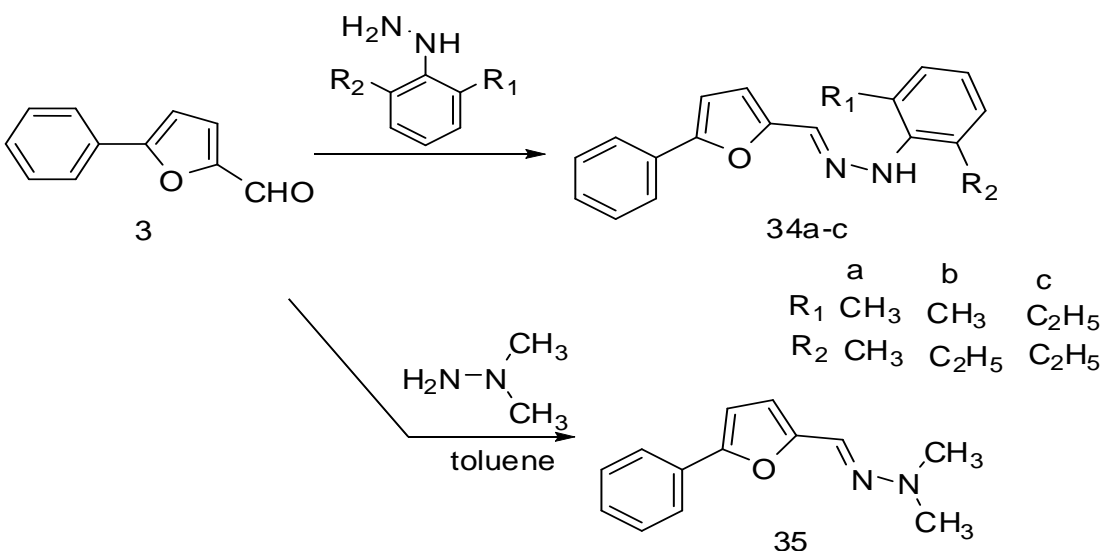

Scheme 34

Reaction of 5-phenyl-2-furaldehyde (3) with arylsulfonohydrazides in anhydrous ethanol afforded a series of the corresponding arylsulfonylhydrazones (36) (Scheme 35) ${ }^{(56)}$.<smiles>[R]c1ccc(S(=O)(=O)NN=Cc2ccc(-c3ccc(C=NNS(=O)(=O)c4ccc([R])cc4)o3)cc2)cc1</smiles>

Scheme 35

Egypt. J. Chem. 58, No. 2 (2015) 
The reaction of 5-phenyl-2-furaldehyde (3) with substituted furo[3,2$b$ pyrrole-5-carbohydrazide in the presence of $p$-toluenesulfonic acid led to $N^{\prime}$ [(5-phenylfuran-2-yl) methylene] -4H-furo[3,2-b] pyrrole-5- carbohydrazide derivatives (37a-d) (Scheme 36$)^{(57)}$

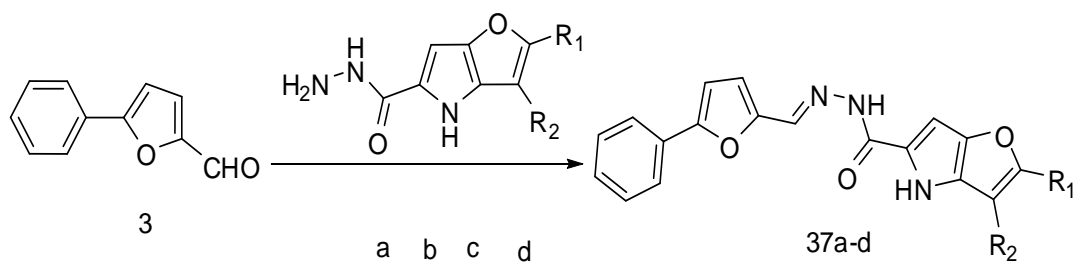

$\mathrm{R}_{1} \mathrm{HCH}_{3} \mathrm{Ph} \mathrm{CH}$

$\mathrm{R}_{2} \mathrm{H} \quad \mathrm{H} \quad \mathrm{H} \mathrm{CH}_{3}$

\section{Scheme 36}

2-[(6,8-Dibromo-2-methylquinazolin $\quad$-4-yl)oxy]- $N$ '- [(5-phenylfuran-2-yl) methylene] acetohydrazide (38) was obtained by treatment of 5-phenyl-2furaldehyde (3) with 4-(acetohydrazide)-6,8- dibromo-2- methylquinazoline (Scheme 37) $^{(12)}$

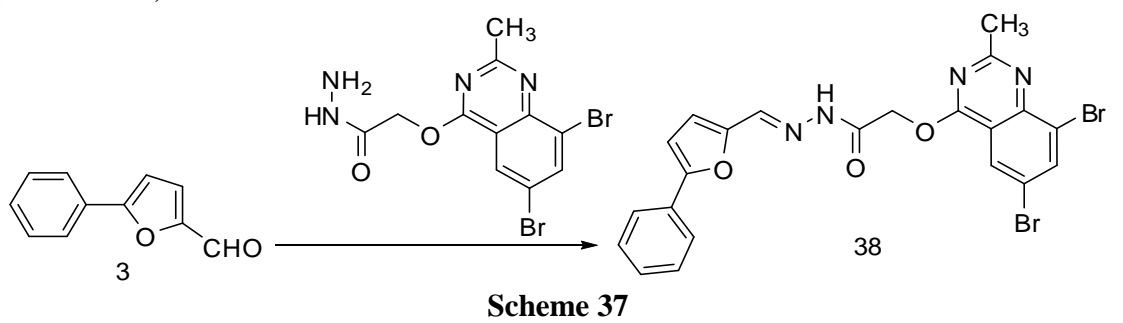

Reaction of 5-phenyl-2-furaldehyde (3) with 8-hydrazino-2-methylfuro $\left[2^{\prime}, 3^{\prime}: 4,5\right]$ pyrrolo[1,2-d] [1,2,4]triazine yielded 5-phenylfuran-2-carbaldehyde (2-methylfuro[2',3':4,5]pyrrolo [1,2-d][1,2,4]triazin-8-yl) hydrazone (39) (yield $50 \%)$ (Scheme 38) ${ }^{(58)}$.<smiles></smiles>

Scheme 38

(3R, 4R)-1- (4-methoxyphenyl) -4-phenyl-3- ((5-phenylfuran-2-yl) methyleneamino) azetidin-2-one (40) was obtained by treatment of 5-phenyl-2-furaldehyde (3) with trans-3amino- $\beta$-lactam in boiling ethanol followed by stirring in dichloromethane at room temperature in the presence of sodium sulfate (Scheme 39) ${ }^{(59)}$. 
<smiles>COc1ccc(N2C(=O)[C@@H](N=Cc3ccc(-c4ccccc4)o3)[C@H]2c2ccccc2)cc1</smiles>

Scheme 39

The condensation of 5-phenyl-2-furaldehyde (3) with 3-aminopropanol at room temperature in the presence of a dehydrating agent $\left(\mathrm{MgSO}_{4}\right)$ yielded 3-[(5phenylfuran-2-yl)methyleneamino]propan-1-ol (41) and 2-(5-phenyl-2-furyl)1,3-oxazinane (42) in an equilibrium mixture (Scheme 40$)^{(60)}$.

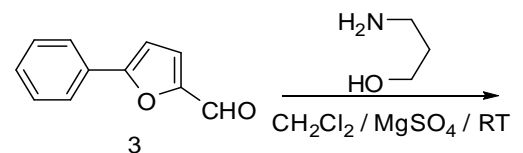<smiles>OCC(/C=N\c1cccc(-c2ccc(C3NCCCO3)o2)c1)CO</smiles>

Scheme 40

Furfuryl alcohol derivatives

The preparation of 2-hydroxymethyl-5-phenylfuran (43) from 5-phenyl-2furaldehyde (3) processed via (i) the reduction by using sodium borohydride $\mathrm{NaBH}_{4}{ }^{(61)}$; (ii) the reduction by $\mathrm{LiAlH}_{4}$ (high yield 96\%); (iii) modified Cannizzaro reaction $^{(62)}$ (Scheme 41).

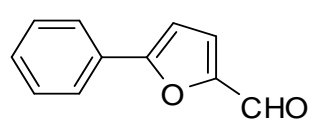

3

\author{
(i) $\mathrm{NaBH}_{4}$ \\ (ii) $\mathrm{LiAlH}_{4}$ \\ (iii) Modified Cannizzaro \\ reaction
}

Scheme 41

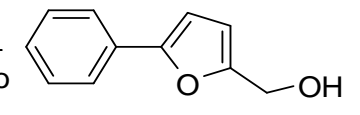

43

1-(5-Phenylfuran-2-yl)ethanol (44) was prepared by the reaction of 5-phenyl2-furaldehyde (3) with methyl magnesium bromide $\mathrm{CH}_{3} \mathrm{MgCl}$ in absolute $\mathrm{Et}_{2} \mathrm{O}$ (yield: 58\%) (Scheme 42) ${ }^{(63)}$.

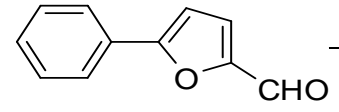

3

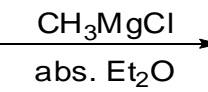

Scheme 42<smiles>CC(O)c1ccc(-c2ccccc2)o1</smiles>

$44 \mathrm{H}_{3} \mathrm{C}$ 
5-Phenyl-2-furaldehyde (3) was converted to (S)-hydroxy(5-phenylfuran-2yl)acetonitrile (45) by enzyme catalysis (Scheme 43) ${ }^{(64)}$.

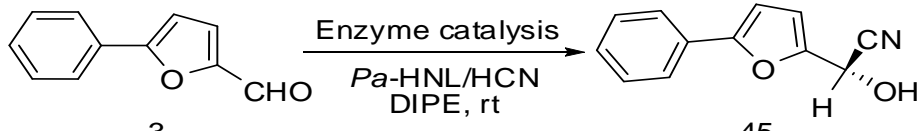

DIPE, rt
Scheme 43

\section{Furancarboxylic acid derivatives}

5-Phenyl-2-furancarboxylic acid (46) was prepared via the oxidation of 5phenyl-2-furaldehyde (3) or by basic hydrolysis of 5-phenyl-2-furonitrile (47) which was prepared through heating of 3 in pyridine with hydroxyl ammonium chloride in acetic anhydride at temperatures not exceeding $95^{\circ} \mathrm{C}^{(65)}$. Also, 5-phenyl-2-furancarboxylic acid (46) can be prepared by coupling of benzene diazonium chloride (1) with 2-furancarboxylic acid in the presence of cupric chloride (Scheme 44) ${ }^{(66)}$.

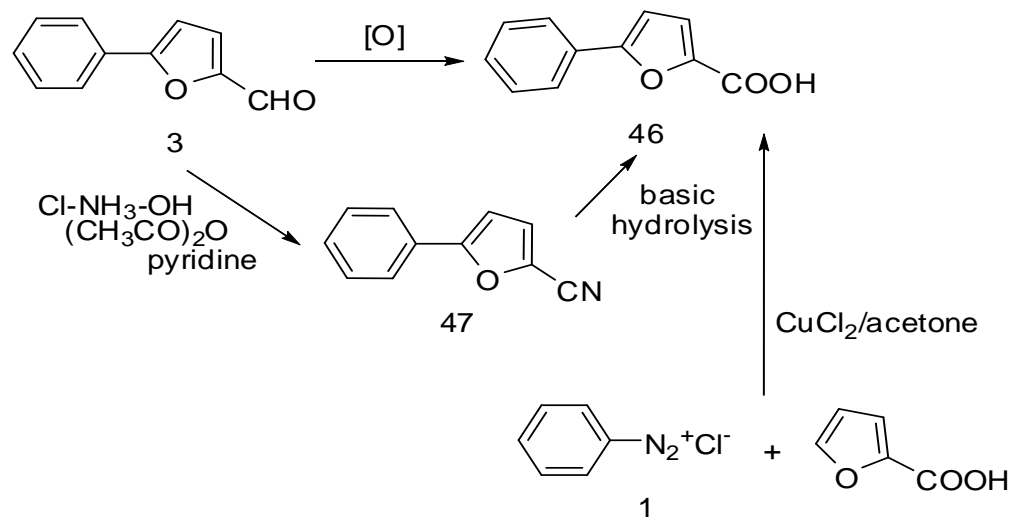

Scheme 44

5-Phenyl-2-furaldehyde (3) was transformed into 2-amino-3-(5-phenylfuran2-yl)propanoic acid (48) via multi-steps reaction (Scheme 45) ${ }^{(67)}$.

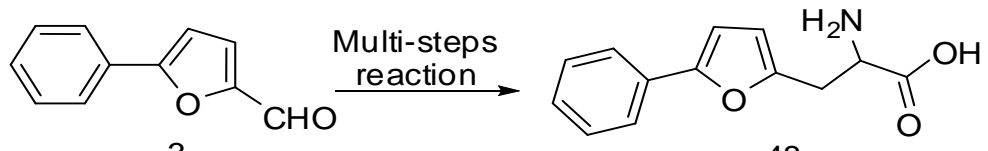

\section{Scheme 45}

Furyl benzothiazole or benzimidazole derivatives

5-Phenyl-2-furaldehyde (3) reacted with 2-methylbenzothiazole in the presence of anhydrous $\mathrm{ZnCl}_{2}$ on heating to $120-180{ }^{\circ} \mathrm{C}$ without a solvent to form 2-[2-(5-phenyl-2-furyl)ethenyl]benzothiazole (49) (Scheme 46) ${ }^{(45)}$.

Egypt. J. Chem. 58, No. 2 (2015) 


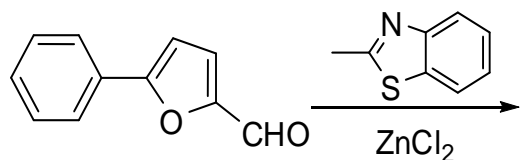

3<smiles>C(=C/c1nc2ccccc2s1)\c1ccc(-c2ccccc2)o1</smiles>

49

Scheme 46

2-(5-Phenyl-2-furyl)benzothiazole (50) (yield: 25\%) was prepared from the reaction of 5-phenyl-2-furaldehyde (3) with $o$-aminothiophenole in pyridine (Scheme 47) ${ }^{(68)}$.

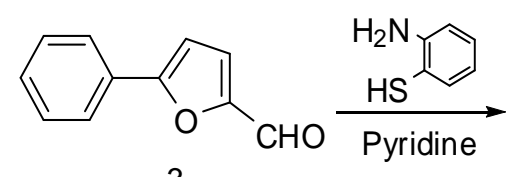

3<smiles>c1ccc(-c2ccc(-c3nc4ccccc4s3)o2)cc1</smiles>

50

Scheme 47

The cyclization of 5-phenyl-2-furaldehyde (3) with 1,2-phenylenediamine or 4-nitro-1,2-phenylenediamine yielded 2-(5-phenyl-2-furyl)benzimidazole (51a) or 2-(5-phenyl-2-furyl)-5-nitrobenzimidazole (51b), respectively, (Scheme 48$)^{(69)}$.

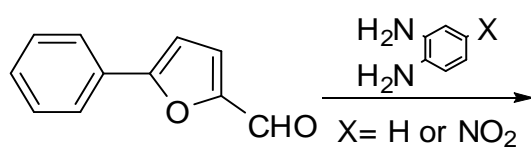

3<smiles>[X]c1ccc2[nH]c(-c3ccc(-c4ccccc4)o3)nc2c1</smiles>

$51 \mathrm{a}, \mathrm{b}$

a; $\mathrm{X}=\mathrm{H}$

b; $\mathrm{X}=\mathrm{NO}_{2}$

Scheme 48

Fused derivatives

The treatment of 5-phenyl-2-furancarbaldehyde (3) with methyl- or ethyl azidoacrylate at $0^{\circ} \mathrm{C}$ in methanol containing sodium metal gave methyl 2azido-3- (5-phenyl-2-furyl) acrylate (52a) or ethyl 2-azido-3- (5-phenyl-2furyl) acrylate (52b), respectively, ${ }^{(70-73)}$. The thermolysis of $52 \mathrm{a}$ or $52 \mathrm{~b}$ in boiling toluene led to methyl $4 H$-2-phenyl-furo [3,2-b] pyrrole-5- carboxylate (53a) or ethyl 2-phenyl-furo [3,2-b] pyrrole-5-carboxylate (53b), respectively, ${ }^{(70-72)}$. Ethyl 2-azido-3- (5-phenyl-2-furyl) acrylate (52b) reacted with triphenylphosphine in dry dichloromethane to give ethyl 2triphenylphosphoimino-3-(5-phenyl-2-furyl) acrylate (54) which reacted with phenyl isocyanate in dry toluene under reflux to give ethyl 2-phenyl-4phenylaminofuro[3,2-c]pyridine-6-carboxylate (55) (Scheme 49) ${ }^{(73)}$.

Egypt. J. Chem. 58, No. 2 (2015) 


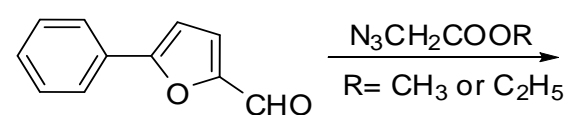

3

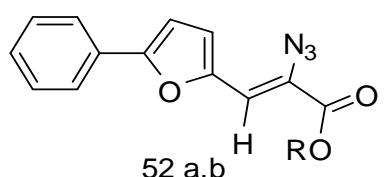

$52 a, b$
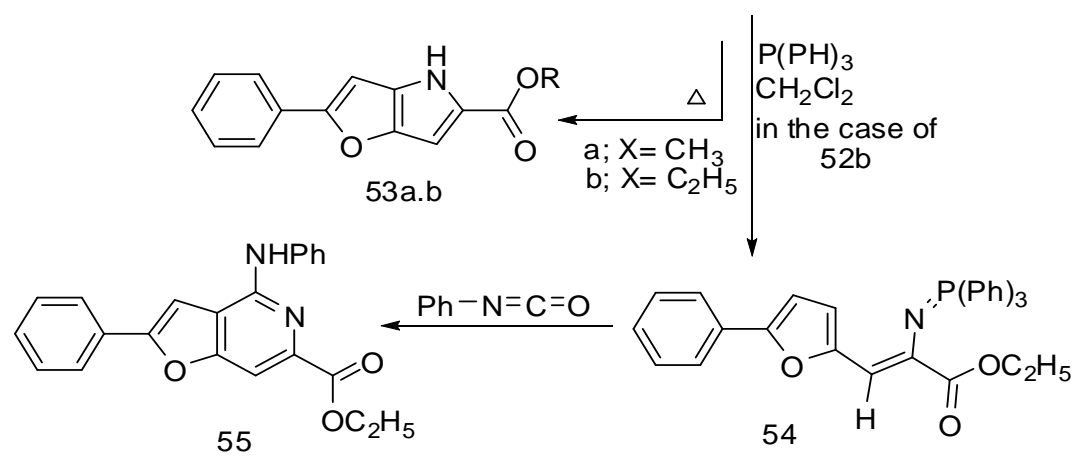

\section{Scheme 49}

Bis and tris derivatives

The conversion of 5-phenyl-2-furancarbaldehyde (3) into 2-hydroxy-1,2bis(5-phenylfuran-2-yl)ethanone (56) takes place in the presence of a base $\left(\mathrm{Et}_{3} \mathrm{~N}\right)$ and thiazolium salt ${ }^{(74)}$. Also, 5-phenyl-2-furancarbaldehyde (3) was converted into tris(5-phenyl-2-furyl)methane (57) by the reaction with ethylene glycol (Scheme 50) ${ }^{(75)}$.

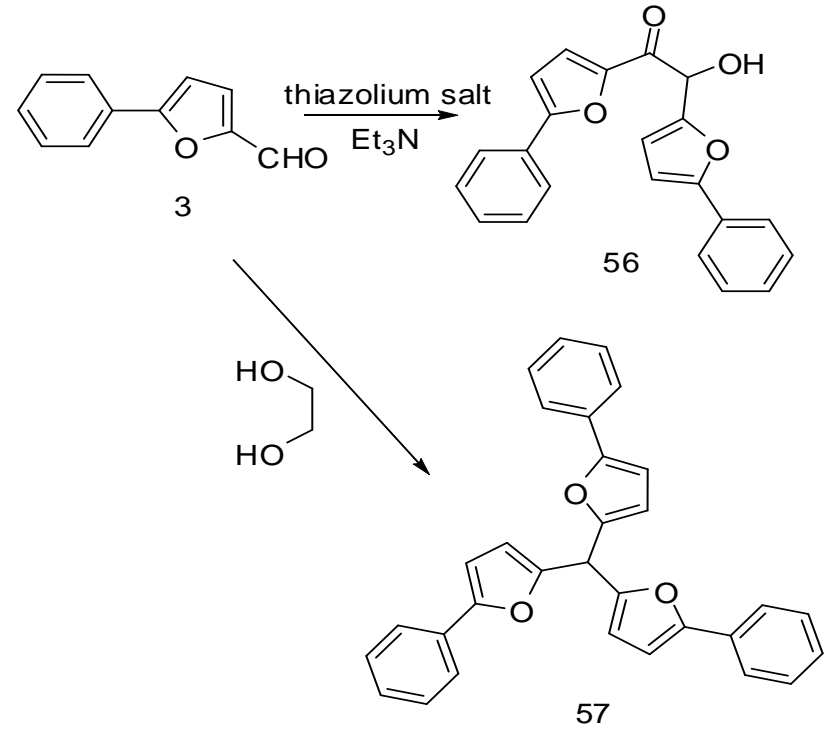

Scheme 50

Egypt. J. Chem. 58, No. 2 (2015) 
Moreover, 3-((1H-indol-3-yl) (5'-phenylfuran-2'-yl) methyl)- $1 H$-indole (58) (yield: $50 \%$ ) was obtained by the condensation of 5-phenyl-2-furancarbaldehyde (3) with indole in dry methanol in the presence of potassium hydrogen sulfate (Scheme 51) ${ }^{(76)}$.

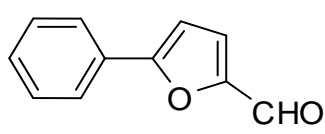

3

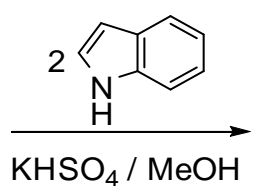

$\mathrm{KHSO}_{4} / \mathrm{MeOH}$<smiles>c1ccc(-c2ccc(C(c3c[nH]c4ccccc34)c3c[nH]c4ccccc34)o2)cc1</smiles>

58

Scheme 51

\section{Metal complex}

2-(5'-Phenylfuran-2'-yl)-1H-imidazo [4,5-f][1,1'] phenanthroline (59) (yield: $60 \%$ ) was prepared by the reaction of 5-phenyl-2-furancarbaldehyde (3) with 1,10-phenanthroline-5,6-dione and ammonium acetate in refluxing glacial acetic acid via the Radziszewski reaction. The complex 60 (yield: 96\%) was obtained by the direct reaction of the ligand 59 with $\mathrm{Ru}(\mathrm{bpy}){ }_{2} \mathrm{Cl}_{2}$ in ethylene glycol under microwave irradiation for 2 min (Scheme 52) ${ }^{(77)}$.

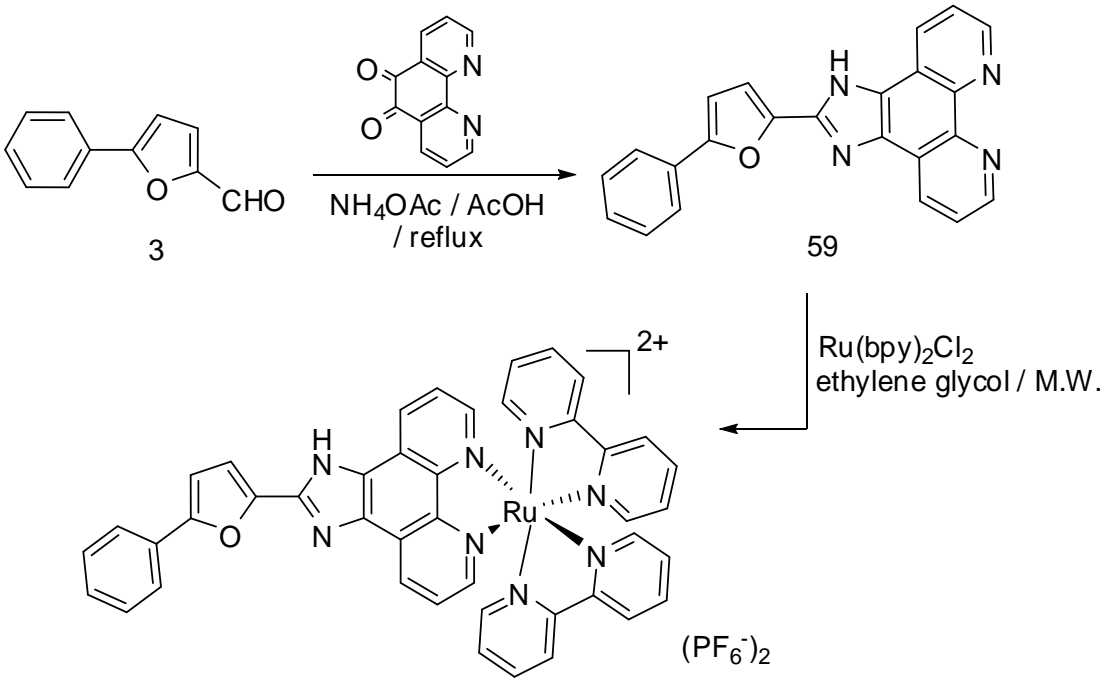

60

Scheme 52

Egypt. J. Chem. 58, No. 2 (2015) 


\section{Biological Activities}

5-Phenyl-2-furaldehyde derivatives exhibit a wide spectrum of pharmacological activities.

\section{Antibacterial activity}

2-[(6,8-Dibromo-2- methylquinazolin-4-yl) oxy]- $N$ '- [(5-phenylfuran-2-yl) methylene]acetohydrazide (38) showed good antibacterial activity against Gram positive and Gram negative bacterial species ${ }^{(12)}$. Also, (Z)-3-methyl-2-(4-oxo-5((5-phenylfuran-2-yl) methylene)-2- thioxothiazolidin-3-yl) pentanoic acid (27a) and (Z)-2-(4-oxo-5- ((5-phenylfuran-2-yl) methylene)-2- thioxothiazolidin-3-yl)3-phenylpropanoic acid (27b), exhibited moderate levels of inhibition against the two Gram-positive bacterial strains (S. aureus KCTC 209 and S. aureus KCTC 503) ${ }^{(47)}$<smiles>[R16]CCC([R])CC</smiles>

\section{Antitumor activity}

(Z)-2-(3,4-Dichlorophenyl)-3-(5-phenyl-2-furyl)acrylonitrile (21) was found to have antitumor activity against a panel of eleven cancer cell lines \{HT29 and SW480 (colon carcinoma), MCF-7 (breast carcinoma), A2780 (ovarian carcinoma), H460 (lung carcinoma), A431 (skin carcinoma), DU145 (prostate carcinoma), BEC-2 (neuroblastoma), SJ-G2 (glioblastoma), MIA (pancreatic carcinoma) and SMA (spontaneous murine astrocytoma) $\}^{(13)}$.

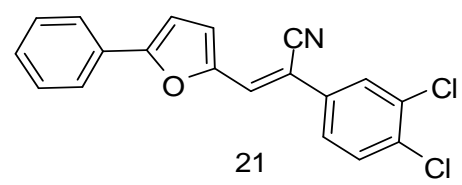

Inhibition of the enzymes

5-[(5-Phenyl-2-furyl)methylene]thiazolidine-2,4-dione (24) has been found as potent and selective inhibitor of phosphoinositide 3-Kinase $\gamma^{(14)}$. Also, (Z)-4methyl- $N$-(2-oxo-5-((5-phenylfuran-2-yl) methylene)-2,5-dihydrothiazol-4-yl) benzenesulfonamide (28) is an inhibitor of HCV NS5B polymerase ${ }^{(15)}$. Moreover, $N$-[3-benzoyl-4- (4-tolylacetylamino)phenyl ]-3-(5-phenyl-2-furyl) acrylic acid amide (61) is an inhibitor of non-thiol farnesyltransferase ${ }^{(16)}$. 
<smiles>O=C1NC(=O)/C(=C/c2ccc(-c3ccccc3)o2)S1</smiles>

24<smiles>Cc1ccc(S(=O)(=O)NC2=NC(=O)S/C2=C\c2ccc(-c3ccccc3)o2)cc1</smiles>

28<smiles>Cc1ccc(CC(=O)Nc2ccc(NC(=O)/C=C/c3ccc(-c4ccccc4)o3)cc2C(=O)c2ccccc2)cc1</smiles>

61

\section{Conclusion}

5-Phenyl-2-furaldehyde has high chemical reactivity due to the presence of the formyl group. This survey is attempted to summarize the synthetic methods, reactions and pharmacological activities of 5-phenyl-2-furaldehyde from 1950 till 2014. From this review, it can be concluded that 5-phenyl-2-furaldehyde and its derivatives display a wide range of pharmacological activities, e.g. antimicrobial and antitumor. They also show inhibition of the enzymes, especially phosphoinositide 3-Kinase $\gamma, \mathrm{HCV}$ NS5B polymerase and non-thiol farnesyltransferase. For that, 5-phenyl-2-furaldehyde and its derivatives have attracted increasing attention of the scientists for the search of new potent pharmacological activity and medicinal activities.

\section{References}

1. Butler, M.S., The role of natural product chemistry in drug discovery. J. Nat. Prod. 67, 2141 (2004).

2. Ivie, G.W., Biological actions and metabolic transformations of furanocoumarins. ACS Symp Ser. 15, 217 (1987).

3. Ding, W., Petibone, D.M. and Latendresse, J.R., In vivo genotoxicity of furan in F344 rats at cancer bioassay doses. Toxicol. Appl. Pharmacol. 261, 164 (2012).

4. Kupchan, S.M., Eakin, M.A. and Thomas, A.M., Tumor inhibitors. 69. Structurecytotoxicity relations among the sesquiterpene lactones. J. Med. Chem. 14, 1147 (1971).

5. Shevchenko, N.E., Synthesis of 3-substituted furylethylamines. Chem. Heterocycl. Compd. 35, 164 (1999).

Egypt. J. Chem. 58, No. 2 (2015) 
6. Qu, S.Y., Wang, B. and Guo, F.L., New diketo-pyrrolo-pyrrole (DPP) sensitizer containing a furan moiety for efficient and stable dye-sensitized solar cells. Dyes Pigm. 92, 1384 (2012).

7. Khan, M.W., Alam, M.J., Rashid, M.A. and Chowdhury, R., A new structural alternative in benzo[b]furans for antimicrobial activity. Bioorg. Med. Chem. 13, 4796 (2005).

8. Hofnung, M., Quillardet, V.M. and Touati, E., Genotoxicity of 2-nitro-7-methoxynaphtho[2,1-b]furan (R7000): a case study with some considerations on nitrofurantoin and nifuroxazide. Res. Microbiol. 153, 427 (2002).

9. Bandurraga, M.M., Fenical, W., Donovan, S.F. and Clardy, J., Pseudopterolide, an irregular diterpenoid with unusual cytotoxic properties from the Caribbean sea whip Pseudopterogorgia acerosa (Pallas) (Gorgonacea). J. Am. Chem. Soc. 104, 6463 (1982).

10. Jin, Y.X., Zhong, A.G. and Ge, C.H., A novel difunctional acylhydrazone with isoxazole and furan heterocycles: syntheses, structure, spectroscopic properties, antibacterial activities and theoretical studies of (E)- $N^{\prime}$-(furan-2-ylmethylene)-5methylisoxazole-4-carbohydrazide. J. Mol. Struct. 1010, 190 (2012).

11. Mamta, R., Mohamad, Y. and Salman, A.K., Synthesis and in vitro-antibacterial activity of [5-(furan-2-yl)-phenyl]-4,5-carbothioamide-pyrazolines. J. Saudi Chem. Soc. 16, 431 (2012).

12. El-Badry, Y.A., Anter, N.A. and El-Sheshtawy, H.S., Synthesis and evaluation of new polysubstituted quinazoline derivatives as potential antimicrobial agents. Der Pharma Chemica, 4, 1361 (2012).

13. Tarleton, M., Gilbert, J., Sakoff, J.A. and McCluskey, A., Cytotoxic 2phenyacrylnitriles, the importance of the cyanide moiety and discovery of potent broad spectrum cytotoxic agents. Eur. J. Med. Chem. 57, 65 (2012).

14. Pomel, V., Covini, J.K.D., Church, D.D., Shaw, J.P., Roulin, K., BurgatCharvillon, F., Valognes, D., Camps, M., Chabert, C., Gillieron, C., Francon, B., Perrin, D., Leroy, D., Gretener, D., Nichols, A., Vitte, P.A., Carboni, S., Rommel, C., Schwarz, M.K. and Rückle, T., Furan-2-ylmethylene thiazolidinediones as novel, potent and selective inhibitors of phosphoinositide 3kinase $\gamma$. J. Med. Chem. 49, 3857 (2006).

15. Ding, Y., Smith, K.L., Varaprasad, C.V.N.S., Chang, E., Alexander, J. and Yao, N., Synthesis of thiazolone-based sulfonamides as inhibitors of HCV NS5B polymerase. Bioorg. Med. Chem. Lett. 17, 841 (2007).

16. Mitsch, A., Wißner, P., Silber, K., Haebel, P., Sattler, I., Klebe, G. and Schlitzer, M., Non-thiol farnesyltransferase inhibitors: $N$-(4-tolylacetylamino -3benzoylphenyl) -3- arylfurylacrylic acid amides. Bioorg. Med. Chem. 12, 4585 (2004). 
17. Akashi, H. and Oda, R., Reaction between furfural and diazo compounds. I. synthesis of arylfurfural. J. Chem. Soc. Japan Ind. Chem. Section, 53, 81 (1950), CA; 47, $2164 f$.

18. Urbański, T., Malinowski, S., Piotrowska, H. and Zakrzewski, L., Roczniki. Chem. 27, 54 (1953); CA; 48,13678.

19. Davis, C.S. and Lougheed, G.S., Synthesis of 5-phenyl-2-furaldehyde. $J$. Heterocycl. Chem. 4, 153 (1967).

20. Antonioletti, R., D'Auria, M., De Mico, A., Piancatelli, G. and Scettri, A., Photochemical synthesis of 3- and 5-aryl-2-furyl derivatives. J. Chem. Soc. Perkin Trans. 1., 7, 1285 (1985).

21. D'Auria, M., Photochemical arylation of furans and thiophenes. Gazz. Chim. Ital. 119, 419 (1989).

22. Itahara, T., Arylation of aromatic heterocycles with arenes and palladium(II) acetate. J. Org. Chem. 50, 5272 (1985).

23. Bussolari, J.C. and Rehborn, D.C., Preparation of 5-aryl furfurals and aryl thiophene-2-carboxaldehydes via palladium-catalyzed $\mathrm{C}-\mathrm{C}$ bond formation in aqueous media ${ }^{1}$. Org. Lett. 7, 965 (1999).

24. Balachari, D., Quinn, L. and O'Doherty, G.A., Efficient synthesis of 5-aryl-2 vinylfurans by palladium catalyzed cross-coupling strategies. Tetrahedron Lett. 40, 4769 (1999).

25. Gauthier, D.R., Szumigala, R.H., Dormer, P.G., Armstrong, J.D., Volante, R.P. and Reider, P.J., Synthesis of 5-pyridyl-2-furaldehydes via palladium-catalyzed cross-coupling with triorganozincates. Org. Lett. 4, 375 (2002).

26. Feuerstein, M., Doucet, H. and Santelli, M., Efficient coupling of heteroaryl bromides with arylboronic acids in the presence of a palladium-tetraphosphine catalyst. Tetrahedron Lett. 42, 5659 (2001).

27. Feuerstein, M., Doucet, H. and Santelli, M., Efficient coupling of heteroaryl halides with arylboronic acids in the presence of a palladium-tetraphosphine catalyst. J. Organomet. Chem. 687, 327 (2003).

28. Tao, B. and Boykin, D.W., Simple amine/Pd(OAc) $)_{2}$-catalyzed Suzuki coupling reactions of aryl bromides under mild aerobic conditions. J. Org. Chem. 69, 4330 (2004).

29. Molander, G.A. and Iannazzo, L., Palladium-catalyzed hiyama cross-coupling of aryltrifluorosilanes with aryl and heteroaryl chlorides. J. Org. Chem. 76, 9182 (2011).

30. Zapf, A., Jackstell, R., Rataboul, F., Riermeier, T., Monsees, A., Fuhrmann, C., Shaikh, N., Dingerdissenb, U. and Beller, M., Practical synthesis of new and highly efficient ligands for the Suzuki reaction of aryl chlorides. Chem. Commun. 38 (2004).

Egypt. J. Chem. 58, No. 2 (2015) 
31. Mino, T., Shirae, Y., Sakamoto, M. and Fujita, T., Phosphine-free hydrazone Pd complex as the catalyst precursor for a Suzuki Miyaura reaction under mild aerobic conditions. J. Org. Chem. 70, 2191 (2005).

32. Phan, N.T.S., Khan, J. and Styring, P., Polymer-supported palladium catalysed Suzuki-Miyaura reactions in batch and a mini-continuous flow reactor system. Tetrahedron, 61, 12065 (2005).

33. Yamada, Y.M.A., Watanabe, T., Beppu, T., Fukuyama, N., Torii, K. and Uozumi, Y., Palladium membrane-installed microchannel devices for instantaneous Suzuki-Miyaura cross-coupling. Chem. Eur. J. 16, 11311 (2010).

34. Rao, M.L.N., Awasthi, D.K. and Talode, J.B., Mono- and biscouplings using triarylbismuths for the atom-efficient arylations of functionalized furans under palladium catalysis arylations of functionalized furans. Synlett. 23, 1907 (2012).

35. Marchalin, Š., Ilavský, D. and Kovǔč, J., Synthese von 3-(5-R-2-furylmethylen)pentan-2,4-dionen. Z. Chem., 27, 406 (1987); CA; 109,149244j.

36. Szemes, F. and Hrnčiar, P., Reactions of 6,7-dihydro-5H-dibenzo[a,c]cyclohepten5,7-dione with aromatic aldehydes. Collect. Czech. Chem. Commun. 39, 3720 (1974).

37. Krutošíková, A., Kováč, J., Frimm, R., Kováč, Š. and Sticzay, T., Furan derivatives. XXVII. Synthesis and absorption spectra of methyl-2-cyano-3-[5-(Xphenyl)-2-furyl]acrylates. Chem. Zvesti. 25, 142 (1971); CA; 75, 48790h.

38. Kada, R., Ilavsky, D., Stetinova, J., Zalibera, L. and Padoura, J., Synthesis, reactions and spectral properties of ethyl esters of 2-cyano-3-(5-x-2-furyl)acrylic acid. Collect. Czech. Chem. Commun. 59, 444 (1994).

39. Litvinov, V.P. and Dyachenko, V.D., Aryl(hetaryl) methylenecyanoselenoacetamides: New convenient reagents for the synthesis of substituted 1,4-dihydro-2-selenoles and selenazoles. Doklady Chemistry 352, 29 (1997).

40. Litvinov, V.P. and Dyachenko, V.D., Cyanoselenoacetamides-new convenient reagents for synthesis of functionally substituted pyridine-2-selenones, 1,4dihydropyridine-2-selenols and selenazoles. Russ. J. Org. Chem. 35, 1377 (1999); CA; 132,334566d.

41. Marchalín, Š., Mamani, L.N.H., Ilavský, D., Prónayová, N. and Leško, J., Synthesis and spectral properties of 2-(5-R-furylmethylene)-3-oxobutanenitriles. Collect. Czech. Chem. Commun. 58, 1388 (1993).

42. Jurášek, A., Kováč, J. and Geisbacher, D., Synthesis and properties of 1-(5-nitro2-furyl)-1-phenylsulfonyl-2-[5-(x-phenyl)-2-furyl] ethylenes. Collect. Czech. Chem. Commun. 39, 1220 (1974).

43. Geisbacher, D., Jurášek, A., Dandárová, M. and Kováč, L., 1-(5-Nitro-2-furyl)-1trichloromethylsulphonyl-2-arylethylenes*. Collect. Czech. Chem. Commun. 43, 1618 (1978) 
44. Jurášek, A., Kováč, J., Kada, R. and Nemlahová, J., Furan derivatives. LXXXIX Synthesis and properties of unsaturated sulfones of the arylfuran series. Chem. Zvesti. 30, 508 (1976); CA; 87,151906x.

45. Ganushchak, N.I., Lesyuk, A.I., Fedorovich, I.S., Obushak, N.D. and Andrushko, V.N., 5-Aryl-2-furaldehydes in the synthesis of 2-substituted 1,3benzazoles. Russ. J. Org. Chem. 39, 1295 (2003); CA; 141,174120j.

46. Sarkis, M., Tran, D.N., Kolb, S., Miteva, M.A., Villoutreix, B.O., Garbay, C. and Braud, E., Design and synthesis of novel bis-thiazolone derivatives as micromolar CDC25 phosphatase inhibitors: Effect of dimerisation on phosphatase inhibition. Bioorg. Med. Chem. Lett. 22, 7345 (2012).

47. Che, J., Zheng, C.-J., Song, M.-X., Bi, Y.-J., Liu, Y., Li, Y.-J., Wu, Y., Sun, L.-P. and Piao, H. R., Synthesis and antibacterial evaluation of furan derivatives bearing a rhodanine moiety. Med. Chem. Res. 23, 426 (2014).

48. Anumala, U.R., Gu, J., Monte, F.L., Kramer, T., Haußen, R.H-., Hölzer, J., Goetschy-Meyer, V., Schön, C., Mall, G., Hilger, I., Czech, C., Herms, J. and Schmidt, B., Fluorescent rhodanine-3-acetic acids visualize neurofibrillary tangles in Alzheimer’s disease brains. Bioorg. Med. Chem. 21, 5139 (2013).

49. Sarkis, M., Tran, D.-N., Lang, M.C.D., Garbay, C. and Braud, E., Convenient synthesis of 5-arylidene-2-imino-4-thiazolidinone derivatives using microwave irradiation 5-arylidene-2-imino-4-thiazolidinone derivatives. Synlett. 25, 1257 (2014).

50. Frimm, R., Kováč, J. and Krutošíková, A., Furan derivatives. XXXI. $\alpha, \beta-$ unsaturated ketones of the phenylfuran series. Chem. Zvesti. 27, 101 (1973); CA; 79, 5195h.

51. Kada, R., Jurášek, A. and Bolcha, J., Synthesis and ultraviolet spectra of 1-(5nitro-2-furyl)-3-(5-(4-x-phenylthio)-2-furyl)-1-propenones*. Collect. Czech. Chem. Commun. 42, 3417 (1977).

52. Hashmi, A.S.K., Hamzić, M., Rominger, F. and Bats, J.W., Gold catalysis: Enantiotopos selection. Chem. Eur. J. 15, 13318 (2009).

53. Nicklaus, C.M., Minnaard, A.J., Feringa, B.L. and de Vries, J.G., Synthesis of renewable fine-chemical building blocks by reductive coupling between furfural derivatives and terpenes. Chem. Sus. Chem. 6, 1631 (2013).

54. Jr, P.P., Burns, W.Y., Jr, W.A. and Jr, E.W.W., 5-Phenyl-2-furamidines: A new chemical class of potential antidepressants. Arzneim.-Forsch./Drug Res. 33, 1411 (1983).

55. Krutošíková, A., Dandárová, M. and Alföldi, J., 5-Aryl-2-furancarbaldehyde hydrazones and related compounds. Collect. Czech. Chem. Commun. 58, 1905 (1993).

Egypt. J. Chem. 58, No. 2 (2015) 
56. Dzikovskaya, L.M. and Ganushchak, N.I., Synthesis of 5-aryl-2-furaldehyde arylsulfonylhydrazones and their transformations in the Bamford-Stevens reaction. Russ. J. Org. Chem. 36, 1346 (2000); CA; 135,92490s.

57. Gašparová, R., Zbojek, D., Lácová, M., Král'ová, K., Gatial, A., Horváth, B. and Krutošíková, A., Reactions of substituted furo[3,2-b]pyrrole-5-carboxhydrazides and their biological activity. Cent. Eur. J. Chem. 3, 622 (2005).

58. Krutosikova, A., Mastik, S., Dandarova, M. and Lycka, A., Synthesis and reactions of 8-hydrazinofuro[2',3':4,5]pyrrolo[1,2-d][1,2,4]triazines. Collect. Czech. Chem. Commun. 62, 1612 (1997).

59. Vazdar, K., Margetić, D. and Habuš, I., Lewis acid promoted diastereoselective Mannich reaction of $\beta$-lactam-tethered aldimines with 1-methoxy-1trimethylsilyloxy-2,2-dimethylethene. Heterocycles, 83, 63 (2011).

60. Zubkov, F.I., Nikitina, E.V., Galeev, T.R., Zaytsev, V.P., Khrustalev, V.N., Novikov, R.A., Orlova, D.N. and Varlamov, A.V., General synthetic approach towards annelated 3a,6-epoxyisoindoles by tandem acylation/IMDAF reaction of furylazaheterocycles. Scope and limitations. Tetrahedron, 70, 1659 (2014).

61. Oleinik, A.F., Vozyakova, T.I. and Novitskii, K.Yu., Syntheses on the basis of arylfurans. Chem. Heterocycl. Comd. 7, 947 (1971).

62. Frimm, R., Krutošíková, A. and Kováč, J., Furan derivatives XXX. Preparation of substituted 5-phenyl-2-furfuryl alcohols. Chem. Zvesti. 26, 551 (1972); CA; 78, 43163h.

63. Hashmi, A.S.K., Hamzić, M., Rudolph, M., Ackermann, M. and Rominger, F., Gold catalysis: Efficient 1,3-induction with diastereotopic homopropargyl alcohols in the phenol synthesis. Adv. Synth. Catal. 351, 2469 (2009).

64. Hashmi, A.S.K., Ata, F., Haufe, P. and Rominger, F., Enantiomerically pure tetrahydroisoquinolines by enzyme catalysis and gold-catalyzed phenol synthesis. Tetrahedron, 65, 1919 (2009).

65. Janda, L. and Votický, Z., Semisynthetic cephalosporins I. An improved synthesis of 5-aryl-2-furancarboxylic acids. Chem. Zvesti.38, 507 (1984); CA; 102, $45718 f$.

66. Burch, H.A., White, R.E., Wright, G.C. and Goldenberg, M.M., Phenylfurans IV: Spasmolytic 3-diethylamino-2,2-(dimethyl)propyl esters of 5-substituted phenyl-2furancarboxylic acids. J. Pharm. Sci. 69, 107 (1980).

67. Paizs, C., Toşa, M.I., Bencze, L.C., Brem, J., Irimie, F.D. and Rétey, J., 2-Amino3-(5-phenylfuran-2-yl)propionic acids and 5-phenylfuran-2-ylacrylic acids are novel substrates of phenylalanine ammonia-lyase. Heterocycles 82, 1217 (2011).

68. Kulenović, V.T., Jakić, L.F. and Lazarević, Z., Synthesis and absorption spectral properties of substituted phenylfurylbenzothiazoles and their vinylogues. Monatshefte für Chemie, 125, 209 (1994). 
69. Kada, R., Kováč, J., Jurášek, A. and Dávid, L., On benzimidazoles. VIII.* preparation and properties of 2-phenylfurylbenzimidazoles. Collect. Czech. Chem. Commun. 38, 1700 (1973).

70. Krutošíková, A., Kováč, J. and Kristofčák, J., Synthesis of substituted 2-aryl-4Hfuro[3,2-b]pyrroles. Collect. Czech. Chem. Commun. 44, 1799 (1979).

71. Krutošíková, A., Dandárová, M. and Alföldi, J., Substituted vinyl azides in the synthesis of condensed nitrogen heterocycies. Chem. Papers , 48, 268 (1994).

72. Umezawa, K., Matsui, A., Nakamura, Y., Citterio, D. and Suzuki, K., Bright, color-tunable fluorescent dyes in the Vis/NIR region: Establishment of new "TailorMade” multicolor fluorophores based on borondipyrromethene. Chem. Eur. J. 15, 1096 (2009).

73. Krutošíková, A., Dandarova, M., Chylova, J. and Vegh, D., Condensed $O-, N-$ heterocycles by the transformation of azidoacrylates. Monatshefte für Chemie, 123, 807 (1992).

74. Hashmi, A.S.K., Wölfle, M., Ata, F., Frey, W. and Rominger, F., Gold catalysis: Desymmetrization in the Furan-Yne reaction. Synthesis, 13, 2297 (2010).

75. Stroganova, T.A., Butin, A.V., Sorotskaya, L.N. and Kul'nevich, V.G., (Aryl)(2furyl)alkanes and their derivatives, $20{ }^{1}$ Synthesis of symmetric bis- and tris(2furyl)methanes. Arkivoc (iv), 641 (2000).

76. Batista, R.M.F., Costa, S.P.G., Silva, R.M.P., Lima, N.E.M. and Raposo, M.M.M., Synthesis and evaluation of arylfuryl-bis(indolyl)methanes as selective chromogenic and fluorogenic ratiometric receptors for mercury ion in aqueous solution. Dyes pigm. 102, 293 (2014).

77. Pedras, B., Batista, R.M.F., Tormo, L., Costa, S.P.G., Raposo, M.M.M., Orellana, G. and Capelo, J.L., Synthesis, characterization, photophysical studies and interaction with DNA of a new family of Ru(II) furyl- and thienyl-imidazophenanthroline polypyridyl complexes. Inorganica Chimica Acta, 381, 95 (2012).

(Received 22/2/2015; accepted 20/4/2015 ) 


\section{5-فينيل-2-فيور الد هيد: تحضير وتفــاعلات والأنشــة البيولوجيـة}

أشرف سيد حسن، سعاد عبدالمجيد عثمان و تغريد شكرى حافظ

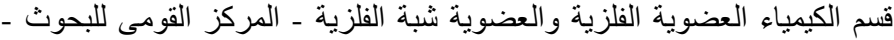

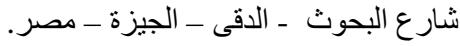

نظراً لأهمية المركب 5-فينيل-2-فيور الدهيد فى تحضير المركبات الحلقية غير

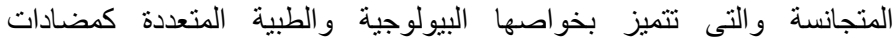

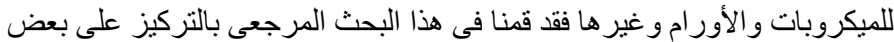

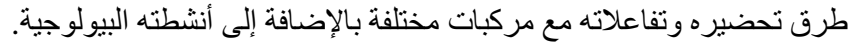

